\title{
PENGETAHUAN DAN SIKAP DENGAN TINDAKAN PERAWAT TENTANG PATIENT SAFETY
}

\author{
Jek Amidos Pardede ${ }^{1}$; Agnes Silvina Marbun²; Muhammad Zikri ${ }^{3}$ \\ ${ }^{1,2,3}$ Program Studi Ners/Fakultas Farmasi dan Ilmu Kesehatan, \\ Universitas Sari Mutiara Indonesia \\ Email: jekpardedemi@rocketmail.com; marbun.agnes@yahoo.co.id; \\ muhammadzikriii24@gmail.com
}

\begin{abstract}
Patient Safety is the avoidance, prevention, and repair of unexpected events or overcome injuries from the health care process. Lack of understanding about patient safety can lead to patient safety events due to a lack of knowledge and attitudes of nurses with nurses' actions about patient safety. Knowledge and attitude are needed to improve patient safety and improve the quality of hospital services. This study aims to determine the relationship between nurses' knowledge and attitudes with actions about patient safety in the Datu Beru Takengon Regional General Hospital. The design of this research is the descriptive correlation with the cross-sectional approach. The study population was implementing nurses, amounting to 273 people and the sample in this study amounted to 67 people using Simple Random Sampling sampling techniques. The statistical test used by Spearman-rho. The results obtained there is a relationship of knowledge with the actions of nurses about patient safety where the value ( $p=0.033 ; p$ $<0.05)$, with a value of $r=0.261$ which means that the strength of the relationship is weak and there is a relationship between attitude and nurses' actions about patient safety where the value of $p=0.047 ; p<0.05$ with a value of $r=0.243$ which means the strength of the relationship is weak. In conclusion, there is a significant relationship between the knowledge and actions of nurses and there is a significant relationship between attitudes and actions of nurses about patient safety.
\end{abstract}

Keywords: knowledge, attitude, actions of nurses, patient safety

\section{PENDULUHUAN}

Rumah sakit merupakan salah satu peningkatan mutu terutama dibidang kesehatan melalui akreditasi rumah sakit menuju pelayanan yang paripurna. Sistem akreditasi yang mengacu pada standar Joint commission International (JCI) diperoleh standar yang paling relevan terkait dengan mutu pelayanan Rumah Sakit International Patient Safety Goals (sasaran international keselamatan pasien) yang meliputi enam sasaran keselamatan pasien rumah sakit (Lombogia et al, 2016).

Keselamatan pasien di rumah sakit (KPRS) adalah system pelayanan dalam suatu Rumah sakit yang memberikan asuhan pasien menjadi lebih aman, termasuk didalamnya mengukur resiko, identifikasi dan pengelolahan resiko terhadap pasien analisa insiden, kemampuan untuk belajar dan menindaklanjuti insiden serta menerapkan solusi untuk mengurangi resiko (Harus \& Sutriningsih, 2015). 
Threats to Australian Patient Safety/TAPS dan penelitian lainnya telah mengidentifikasi dua jenis insiden keselamatan pasien yang luas, Insiden pertama terkait dengan proses perawatan, termasuk proses administrasi, investigasi, perawatan, komunikasi dan pembayaran. Ini adalah jenis kejadian umum yang dilaporkan (berkisar antara 70\%-90\% tergantung pada penelitian). Sedangkan insiden yang kedua Insiden terkait dengan pengetahuan atau keterampilan praktisi, termasuk diagnosis yang tidak terjawab atau tertunda, perlakuan salah dan kesalahan dalam pelaksanaan tugas (Tutiany \& Krisanti, 2017).

Menurut Bawelle, et al (2013) secara keseluruhan program patient safety sudah diterapkan, namun masalah dilapangan merujuk pada konsep patient safety, karena walaupun sudah pernah mengikuti sosialisasi, tetapi masih ada pasien cedera, resiko jatuh, resiko salah pengobatan, pendelegasian yang tidak akurat saat operan pasien yang mengakibatkan keselamatan pasien menjadi kurang maksimal. Peningkatan keselamatan terbukti sulit untuk dipertahankan dan disebarkan, dengan penelitian yang mengkonfirmasikan belum ada peningkatan tingkat sistem yang dapat diukur dalam keseluruhan tingkat bahaya yang dapat dicegah (Mannion \& Braithwaite, 2017)
Kesalahan yang mengakibatkan pasien cedera dapat berupa ketidaktepatan identifikasi pasien yang berakibat kesalahan atau keterlambatan diagnosis, kegagalan dalam bertindak, kesalahan pengobatan, dan kesalahan dosis atau metode dalam pemberian obat. Sasaran keselamatan pasien lainnya yang perlu diperhatikan untuk menghindari cedera pada pasien berupa peningkatan keamanan obat yang perlu diwaspadai, pengurangan resiko infeksi terkait pelayanan kesehatan, dan pengurangan resiko jatuh.

Menurut Darlinana (2016) Upaya penerapan patient safety sangat tergantung dari pengetahuan perawat. Apabila perawat menerapkan patient safety didasari oleh pengetahuan yang memadai, maka perilaku patient safety oleh perawat tersebut bersifat langgeng (long lasting). Seorang perawat dalam memberikan asuhan keperawatan harus memiliki pengetahuan yang benar, keterampilan, dan sikap untuk menangani kompleksitas perawatan kesehatan.

National Patient Safety Agency (NPSA) 2017 melaporkan dalam rentang waktu Januari-Desember 2016 angka kejadian insiden keselamatan pasien (IKP) yang dilaporkan dari negara Inggris sebanyak 1.879 .822 kejadian. Ministry of Health Malaysia 2013 melaporkan angka insiden keselamatan 
pasien dalam rentang waktu JanuariDesember sebanyak 2.769 kejadian dan untuk negara Indonesia dalam rentang waktu 2006-2011. Komite Keselamatan Pasien Rumah Sakit (KKPRS) melaporkan terdapat 877 kejadian insiden keselamatan pasien. Penelitian tentang keselamatan pasien menyebabkan Kejadian Tidak Diharapkan (KTD) di 26 negara berpenghasilan menengah dan rendah, frekuensi KTD berkisar 8\% dengan 83\% KTD tersebut dapat dicegah, dan dengan angka kematian sebesar 30\%. Angka estimasi hospitalisasi setiap tahun di dunia adalah sebesar 421 juta dengan sekitar 42,7 juta pasien mengalami KTD (WHO, 2017). Kesalahan medis merupakan permasalahan terbesar dalam keselamatan pengobatan dan menjadi salah satu indikator pencapaian keselamatan pasien sehingga menjadi semakin penting dalam bidang penelitian medis dalam beberapa tahun terakhir (Sultana et al., 2018).

Beberapa penelitian yang sudah diteliti peneliti sebelumnya tentang patient safety. Hasil penelitian Anriani (2019) di RS Panti Waluya Sawahan Malang, diperoleh hasil pre-test 200 peserta tentang pengetahuan keselamatan pasien rumah sakit didapatkan sebagian besar (89\%) mendapatkan nilai kurang (60\%) dan sisanya (11\%) mendapatkan nilai baik
(>75). Jumlah insiden yang masuk di tim KPRS tercatat 22 insiden sebagai berikut KTD (Kejadian tidak diharapkan) 9 insiden (41 \%), KNC (Kejadian nyaris cedera) 6 insiden (27\%), KPC (Kejadian Potensial Cedera) 5 insiden (23\%), KTC (Kejadian tidak cedera) 2 insiden (9\%). Hasil penelitian Cahyono (2015) teradapat hubungan antara tingkat pengetahuan perawat terhadap praktek keselamatan pasien, yingkat pengetahuan mayoritas baik $67,9 \%$ dan penegelolaan keselamatan pasien mayoritas baik 76,7\%. Hasil penelitian Bawelle, et al (2013) di Ruang Rawat Inap RSUD Liun Kendage Tahuna, bahwa ada hubungan yang signifikan antara sikap perawat dengan pelaksanaan keselamatan pasien (patient safety), dimana $95 \%$ perawat pelaksana mempunyai sikap yang baik dalam melaksanakan keselamatan pasien.

Hasil penelitian Darliana (2016) di ruang rawat inap RSUD dr. Zainoel Abidin Banda Aceh dengan 67 responden, didapatkan pengetahuan perawat mayoritas cukup $43 \%$ dan upaya penerapan patient safety mayoritas kurang 64,2\% serta ada hubungan pengetahuan perawat dengan upaya penerapan patient safety. Hasil penelitian Bantu, et al (2014) di RSUP Ratatotok Buyat Kabupaten Minahasa Tenggara, terdapat pengetahuan perawat 
mayoritas baik $75 \%$ dan patient safety diterapkan $52,1 \%$ serta ada hubungan yang signifikan antara pengetahuan perawat dengan penerapan identify patient correctly. Hasil penelitian Listianawati (2018) di ruang rawat inap kelas III RSUD dr. Loekmono Hadi Kudus, terdapat pengetahuan perawat tentang patient safety mayoritas baik $87,9 \%$ dan sikap perawat dalam memberian obat mayoritas baik $94,8 \%$ serta ada hubungan yang signifikan antara pengetahuan perawat tentang keselamatan pasien dengan sikap perawat terhadap pemberian obat.

Berbeda dengan hasil penelitian Renoningsih (2016) Tidak ada hubungan sikap perawat dengan penerapan patient safety di Instalasi Rawat Inap Rumah Sakit Umum Pancaran Kasih GMIM Manado. Sedangkan Hasil penelitian Asfian, et al (2019) di Rumah Sakit Santa Anna Kendari. Hasil penelitian ini menunjukan bahwa ada hubungan antara sikap dengan pelaksanaan patient safety. Sedangkan pengetahuan dan motivasi tidak berhubungan dengan pelaksanaan patient safety. Menurut (Mannion \& Braithwaite, 2017) upaya yang dilakukan saat ini untuk membuat sistem perawatan kesehatan lebih aman dan menunjukkan pendekatan baru dan yang muncul untuk memahami dan menangani keselamatan pasien dalam sistem kesehatan yang kompleks dan dinamis.

Berdasarkan hasil survei dan observasi awal yang dilakukan oleh peneliti pada di RSUD Datu Beru peneliti mewawancarai beberapa orang perawat. Saat peneliti melakukan wawancara kepada perawat yang sedang bertugas bagaimana pelaksanaan patient safety perawat kurang mengetahui apa saja sasaran dan banyaknya jumlah pasien membuat beban kerja yang menyebabkan kurangnya pengawasan terhadap pelaksanaan patient safety. Hasil wawancara ditemukan kasus Kejadian Tidak Diharapkan (KTD) yang mana disebabkan oleh perawat atau pasien itu sendiri, seperti pasien terjatuh di kamar mandi dikarenakan pasien dalam kondisi lemah dan bangun dari tempat tidur tanpa sepengetahuan perawat. Perawat mengeluhkan kurangnya fasilitas rumah sakit karena sebagian bed tidak memiliki restrain, dan kurangnya pengetahuan perawat untuk menyelesaikan masalah atau mencari solusi apabila bed tidak memiliki restrain. Perawat juga tidak cuci tangan sebelum kontak dengan pasien, perawat hanya melakukan cuci tangan pada saat selesai kontak dengan pasien dan menyebabkan pasien mengalami infeksi nosokomial dan pasien menambah jumlah rawatannya. 
Berdasarkan latar belakang di atas, peneliti tertarik melakukan penelitian tentang Hubungan Pengetahuan dan Sikap dengan Tindakan Perawat Tentang Patient Safety. Tujuan penelitian ini untuk memastikan hubungan kedua variabel karena peneliti sebelumnya mendapatkan ada hubungan yang signifikan antara pengetahuan dan sikap dengan penerapan patient safety tetapi ada juga didapatkan tidak ada hubungan yang signifikan antara sikap dengan motivasi dan penerapan patient safety.

\section{METODE}

Desain penelitian yang digunakan adalah deskriptif korelasi dengan menggunakan pendekatan cross sectional karena peneliti hanya melakukan satu kali penelitian terhadap subjek yang diteliti dalam waktu yang bersamaan untuk mengetahui hubungan antara dua variabel bebas (Pengetahuan dan sikap perawat) dan variabel terikat (Tindakan perawat tenatng patient safety) di RSUD Datu Beru Takengon tahun 2018. Populasi penelitian adalah perawat pelaksana yang berjumlah 273 orang dan sampel dalam penelitian ini berjumlah 67 orang dengan teknik pengambilan sampel menggunkan simple Random Sampling.

Pengumpulan data dengan menggunakan kuesioner 30 pernyataan tentang pengetahuan yang telah di uji validitas dan reliabilitas dengan cronbach alpha 0,891, dan untuk kuesioner sikap terdapat 30 pernyataan dengan cronbach alpha 0,917 serta 30 pernyataan tentang tindakan dengan cronbach alpha 0,853 . Uji statistik yang digunakan Spearman-rho dengan nilai $p$ $<0.05$.

\section{HASIL DAN PEMBAHASAN}

\section{Hasil}

Tabel 1. Rata-rata Karakteristik Responden Berdasarkan Umur

\begin{tabular}{lcccc}
\hline \multicolumn{1}{c}{ Usia } & Minimum & Maksimum & Mean & $\begin{array}{c}\text { Std. } \\
\text { Deviation }\end{array}$ \\
\hline $\begin{array}{l}\text { Perawat } \\
\text { Pelaksana }\end{array}$ & 22 & 47 & 29,88 & 4,457 \\
\hline
\end{tabular}

Berdasarkan Tabel 1, dapat dilihat ratarata usia responden 29,88 sehingga digenapkan menjadi 30 tahun dengan usia terendah 22 tahun dan tertinggi 47 tahun. 
Tabel 2. Distribusi Frekuensi dan Persentase Berdasarkan Jenis Kelamin, Pendidikan, Pelatihan Perawat

\begin{tabular}{lrr}
\hline \multicolumn{1}{c}{ Karakteristik } & n & \multicolumn{1}{c}{$\%$} \\
\hline Jenis Kelamin & & \\
Laki-laki & 22 & 32,8 \\
Perempuan & 45 & 67,2 \\
\hline Pendidikan & & \\
SPK & 1 & 1,5 \\
D3 & 25 & 37,3 \\
D4 & 6 & 9,0 \\
S1 & 7 & 10,4 \\
Ners & 28 & 41,8 \\
\hline Pelatihan & & \\
Pernah & 33 & 49,3 \\
Tidak Pernah & 34 & 50,7 \\
\end{tabular}

Berdasarkan Tabel 2, dapat dilihat jenis kelamin responden mayoritas perempuan sebanyak 45 orang $(67,2 \%)$. Pendidikan terakhir responden mayoritas Ners sebanyak 28 orang $(41,8 \%)$. Sedangkan pelatihan mayoritas tidak pernah sebanyak 34 orang $(50,7 \%)$.

Tabel 3. Distribusi Frekuensi dan persentase berdasarkan Pengetahuan Perawat tentang Patient Safety

\begin{tabular}{lcc}
\hline \multicolumn{1}{c}{$\begin{array}{c}\text { Pengetahuan } \\
\text { Perawat }\end{array}$} & n & \% \\
\hline Baik & 33 & 49,3 \\
Cukup & 26 & 38,8 \\
Kurang & 8 & 11,9 \\
\hline
\end{tabular}

Berdasarkan Tabel 3, dapat dilihat bahwa pengetahuan responden mayoritas baik sebanyak 33 responden (49.3\%) dan pengetahuan yang cukup sebanyak 26 responden $(38,8 \%)$ serta pengetahuan yang kurang sebanyak 8 responden $(11,9 \%)$.

\section{Tabel 4. Distribusi Frekuensi dan Persentase Berdasarkan Sikap Perawat Tentang Patient Safety}

\begin{tabular}{lcc}
\hline \multicolumn{1}{c}{ Sikap Perawat } & n & \% \\
\hline Baik & 30 & 44,8 \\
Kurang & 37 & 55,2 \\
\hline
\end{tabular}

Berdasarkan Tabel 4, dapat dilihat sikap responden mayoritas kurang sebanyak 37 responden (55.2\%) dan sikap perawat yang baik sebanyak 30 responden $(44,8 \%)$.

Tabel 5. Distribusi Frekuensi dan Persentase Berdasarkan Tindakan Perawat Tentang Patient Safety

\begin{tabular}{lcc}
\hline $\begin{array}{l}\text { Tindakan } \\
\text { Perawat }\end{array}$ & n & \% \\
\hline Baik & 29 & 43,3 \\
Kurang & 38 & 56,7 \\
\hline
\end{tabular}

Berdasarkan Tabel 5, dapat dilihat bahwa tindakan responden mayoritas kurang sebanyak 38 responden (56.7\%).

Tabel 6. Hubungan Pengetahuan Perawat dengan Tindakan Perawat Tentang Patient Safety

\begin{tabular}{|c|c|c|c|c|c|c|c|c|}
\hline \multirow{3}{*}{$\begin{array}{c}\text { Pengetahuan } \\
\text { Perawat }\end{array}$} & \multicolumn{4}{|c|}{ Tindakan Perawat } & \multirow{2}{*}{\multicolumn{2}{|c|}{ Total }} & \multirow{3}{*}{$r$} & \multirow{3}{*}{ p value } \\
\hline & \multicolumn{2}{|c|}{ Baik } & \multicolumn{2}{|c|}{ Kurang } & & & & \\
\hline & $\mathrm{n}$ & $\%$ & $\mathrm{n}$ & $\%$ & $\mathrm{n}$ & $\%$ & & \\
\hline Baik & 18 & 26.9 & 15 & 22.4 & 33 & 49.3 & & \\
\hline Cukup & 10 & 14.9 & 16 & 23.9 & 26 & 38.8 & 0.261 & 0.033 \\
\hline Kurang & 1 & 1.5 & 7 & 10.4 & 8 & 11.9 & & \\
\hline Jumlah & 29 & 43.3 & 38 & 56.7 & 67 & 100 & & \\
\hline
\end{tabular}


Berdasarkan Tabel 6, dapat dilihat bahwa pengetahuan perawat baik sebanyak 33 responden (49.3\%) dengan tindakan perawat baik sebanyak 18 responden (26.9\%) dan tindakan perawat kurang sebanyak 15 responden (22.4\%). Sedangkan pengetahuan perawat cukup sebanyak 26 responden (38.8\%) dengan tindakan perawat baik sebanyak 10 responden (14.9\%) dan tindakan perawat kurang 16 responden (23.9\%). Kemudian pengetahuan perawat kurang sebanyak 8 responden
(11.9\%) dengan tindakan perawat baik sebanyak 1 responden (1.5\%) dan tindakan perawat kurang sebanyak 7 responden (10.4\%). Hasil uji SpearmanRho dapat dilihat ada hubungan yang signifikan antara pengetahuan dengan tindakan perawat tentang patient safety dengan pvalue $=0,033(p<0,05)$ dan nilai $r=0,261$ menunjukkan kekuatan yang lemah antara pengetahuan perawat dengan tindakan perawat tentang patient safety.

Tabel 7. Hubungan Sikap Perawat Dengan Tindakan Perawat Tentang Patient Safety

\begin{tabular}{|c|c|c|c|c|c|c|c|c|}
\hline \multirow{3}{*}{$\begin{array}{c}\text { Sikap } \\
\text { Perawat }\end{array}$} & \multicolumn{4}{|c|}{ Tindakan Perawat } & \multirow{2}{*}{\multicolumn{2}{|c|}{ Total }} & \multirow{3}{*}{$\boldsymbol{r}$} & \multirow{3}{*}{$p$ value } \\
\hline & \multicolumn{2}{|c|}{ Baik } & \multicolumn{2}{|c|}{ Kurang } & & & & \\
\hline & $\mathbf{n}$ & $\%$ & $\mathbf{n}$ & $\%$ & $\mathbf{n}$ & $\%$ & & \\
\hline Baik & 17 & 25.4 & 13 & 19.4 & 30 & 44.8 & & \\
\hline Kurang & 12 & 17.9 & 25 & 37.3 & 37 & 55.2 & $\begin{array}{c}0.24 \\
3\end{array}$ & 0.047 \\
\hline Jumlah & 29 & 43.3 & 38 & 56.7 & 67 & 100 & & \\
\hline
\end{tabular}

Berdasarkan Tabel 7, dapat dilihat bahwa sikap perawat baik sebanyak 30 responden (44.8\%) dengan tindakan perawat baik sebanyak 17 (25.4\%) dan tindakan perawat kurang sebanyak 13 responden (19.4\%). Sedangkan sikap perawat kurang sebanyak 37 responden (55.2\%) dengan tindakan perawat baik sebanyak 12 (17.9\%) dan tindakan perawat kurang 25 responden $(37.3 \%)$. Hasil uji Spearman-Rho dapat dilihat ada hubungan yang signifikan antara sikap dengan tindakan perawat tentang patient safety dengan pvalue $=0,047$ $(p<0,05) \quad$ dan nilai $\quad r=0,243$ menunjukkan kekuatan yang lemah antara sikap perawat dengan tindakan perawat tentang patient safety

\section{Pembahasan}

Pengetahuan Perawat tentang Patient Safety

Berdasarkan hasil penelitian yang dilakukan menunjukkan bahwa pengetahuan perawat mayoritas baik, hal ini diperoleh dari hasil jawaban responden sebanyak 64 responden menjawab bahwa keselamatan pasien proses dalam suatu rumah sakit yang memberikan pelayanan pasien yang lebih aman dan mengurangi angka 
kejadian keselamatan pasien di rumah sakit, ini menunjukkan responden memiliki pengetahuan yang baik. Hal ini sejalan dengan penelitian yang dilakkukan oleh Listianawati (2018) didapatkan pengetahuan perawat tentang pastient safety mayoritas baik $87,9 \%$.

Hasil penelitian tingkat pendidikan tertinggi responden Ners dimana pengetahuan dan pemahaman responden lebih baik dari pada yang berpendidikan SPK, D3, D4 dan S1. Pengetahuan dan pemahaman responden mungkin lebih baik pada tingkat pendidikan yang lebih tinggi, artinya responden yang memiliki pendidikan lebih tinggi akan mempunyai pengetahuan yang lebih luas. Menurut Setiyajati (2014) upaya untuk meningkatkan pengetahuan dan pendidikan merupakan suatu hal yang penting dalam konteks keselamatan pasien karena pengetahuan menunjang keterampilan yang dapat dipertanggungjawabkan.

Asumsi peneliti pengtahuan perawat dapat bertambah dengan meninkatkan pendidikan yang dapat dipertanggungjawabkan dan terbukti dengan hasil penelitian ini bahwa responden lebih banyak yang berpendidikan Ners sehingga hasil yang didapatkan pengetahuan dan tindakan yang baik.

\section{Sikap Perawat tentang Patient Safety}

Berdasarkan hasil penelitian yang dilakukan menunjukkan bahwa sikap perawat mayoritas kurang, hal ini diperoleh dari hasil jawaban responden yang mana menjawab sangat tidak setuju bahwa perawat memerlukan pelatihan lebih ketat dalam cuci tangan untuk tindakan keperawatan khusus untuk pasien penyakit menular atau pasien isolasi.

Penelitian ini selaras dengan hasil penelitian Asfian, et al (2019) didapatkan responden memiliki sikap kurang, dikarenakan pembentukan sikap dipengaruhi oleh kurangnya kepatuhan dan tanggung jawab setiap perawat dengan pelaksanaan patient safety itu sendiri.Sikap pada hakikatnya bukan merupakan faktor bawaan yang tidak dapat diubah. Sikap diperoleh, diubah, ditingkatkan atau diturunkan melalui salah satu atau kombinasi dari empat sumber yang mempengaruhi sikap yaitu pengalaman dan tanggung jawab menyelesaikan masalah, pengalaman orang lain, keadaan fisiologis dan emosional.

Peneliti berasumsi kurangnya tanggung jawab perawat dengan pelaksanaan patient safety, dapat dilihat dari jawaban kusioner perawat lebih cenderung tidak setuju dengan mengkuti pelatihan karena perawat merasa bahwa mengikuti pelatihan adalah ketat dan 
ilmu yang didapat dibangku kuliah dengan pengalamnya bekerja sudah merasa cukup sehingga tidak mencerminkan sikap yang baik karena sikap merupakan reaksi atau respon tertutup seseorang terhadap stimulus atau objek tertentu, yang sudah melibatkan faktor pendapat dan emosi yang bersangkutan (senang tidak senang, setuju tidak setuju, baik tidak baik).

\section{Tindakan Perawat tentang Patient Safety}

Hasil penelitian yang dilakukan menunjukkan mayoritas responden kurang dalam tindakan asuhan keperawatan patient safety. Hal ini diperoleh dari hasil observasi responden tidak dilakukan karena perawat tidak selalu memperkenalkan diri kepada pasien. Peneliti mengobservasi bahwa responden hanya memperkenalkan diri saat pergantian shift dan merasa sudah kenal dengan pasiennya itu sendiri. Hal ini menunjukkan bahwa tindakan bisa berhubungan dengan pengetahuan perawat semakin baik pengetahuan akan mempengaruhi seseorang dalam melakukan sebuah tindakan karena menyangkut hidup seseorang.

Hal ini sejalan dengan penelitian Listianawati (2018) menunjukkan bahwa yang memiliki hubungan dengan tindakan penerapan patient safety adalah pengetahuan, semakin pengetahuan baik maka tindakan akan baik juga. Keberhasilan tindakan perlu didukung adanya kepatuhan pribadi perawat tersebut. Sehingga para perawat diharapkan dapat meningkatkan kepatuhan tindakan sesuai dengan standar operasional prosedur dalam pencegahan pasien jatuh.

\section{Hubungan Pengetahuan Dengan Tindakan Perawat Tentang Patient Safety}

Berdasarkan hasil penelitian di dapatkan perawat pelaksana diperoleh hasil tingkat pengetahuan responden baik dalam melakukan tindakan patient safety dan ada juga pengetahuan responden yang kurang dan kurang dalam melakukan tindakan patient safety. Hal ini diperoleh dari hasil jawaban responden sebanyak 64 responden menjawab bahwa keselamatan pasien proses dalam suatu rumah sakit yang memberikan pelayanan pasien yang lebih aman dan mengurangi angka kejadian keselamatan pasien di rumah sakit. Menurut pendapat peneliti bahwa ada hubungan yang signifikan antara pengetahuan dengan tindakan perawat tentang patient safety karena semakin baik pengetahuan perawat maka semakin baik tindakan perawat, sebaliknya pengetahuan perawat yang kurang maka tindakan perawat akan kurang. Berdasarkan hasil uji statistik menggunakan uji Spearmanrho didapatkan ada hubungan 
pengetahuan dengan tindakan perawat tentang patient safety di rumah sakit umum daerah Datu Beru Takengon.

Penelitian yang dilakukan oleh Bawelle (2013) bahwa terdapat hubungan antara pengetahuan perawat dengan pelaksanaan keselamatan pasien (patient safety). Penelitian ini didukung oleh Darliana (2016) terdapat hubungan pengetahuan perawat dengan upaya penerapan patient safety" menunjukkan bahwa mayoritas responden yang memiliki tingkat pengetahuan yang tinggi 25 responden dan pengetahuan rendah 13 responden. Hasil uji statistik menunjukkan terdapat hubungan yang signifikan antara tingkat pengetahuan dengan upaya penerapan patient safety. Dimana responden yang melakukan penerapan patient safety diharapkan mempunyai pengetahuan dan pemahaman.

Peneliti berasumsi bahwa apabila pengetahuan perawat baik mempengaruhi tindakan perawat dalam melakukan sesuatu tindakan. Sebaliknya apabila pengetahuan kurang maka tindakan yang dilakukan perawat tentang patient safety tersebut kurang dan dari hasil penelitian pengetahuan perawat yang baik diperoleh tindakan perawat masih ada yang kurang dan pengetahuan perawat yang kurang dan ada yang tindakan tentang patient safety baik. Hal ini menunjukkan pengetahuan tidak dapat dijadikan indikator dalam melakukan tindakan.

\section{Hubungan Sikap Dengan Tindakan Perawat Tentang Patient Safety}

Berdasarkan hasil penelitian di dapatkan perawat pelaksana diperoleh hasil sikap perawat baik dalam melakukan tindakan patient safety dan sikap perawat yang kurang dalam melakukan tindakan patient safety. Hal ini diperoleh dari hasil jawaban respon sebanyak 25 responden menjawab sangat tidak setuju bahwa perawat memerlukan pelatihan lebih ketat dalam cuci tangan untuk tindakan keperawatan khusus untuk pasien penyakit menular atau pasien isolasi. Menurut pendapat peneliti bahwa ada hubungan yang signifikan antara sikap dengan tindakan perawat tentang patient safety, karena semakin baik sikap perawat maka semakin baik tindakan perawat tentang patient safety, sebaliknya sikap perawat yang kurang maka tindakan perawat untuk patient safety akan kurang.

Penelitian ini didukung oleh penelitian yang dilakukan oleh Asfian, et. al (2019) bahwa mayoritas responden memiliki sikap yang kurang dan memiliki sikap kurang tetapi melaksanakan patient safety cukup. Hasil uji statistik menunjukkan terdapat hubungan sikap perawat dengan pelaksanaan patient safety. 
Sejalan dengan hasil penelitian Setiyajati (2014) bahwa terdapat hubungan yang bermakna antara sikap perawat dengan penerapan keselamatan pasien (patient safety). Peneliti berasumsi bahwa apabila sikap perawat baik akan mempengaruhi tindakan perawat dalam melakukan sesuatu tindakan. Sebaliknya apabila sikap kurang maka tindakan yang dilakukan perawat tentang patient safety tersebut kurang.

\section{KESIMPULAN DAN SARAN}

\section{Kesimpulan}

Ada hubungan yang signifikan antara Pengetahuan dan sikap dengan tindakan perawat tentang patient safety

\section{Saran}

Perawat dapat menerapkan dan meningkatkan mutu pelayanan untuk meningkatkan keselamatan pasien, memperbaiki sikap mengikuti pelatihanpelatihan yang diadakan rumah sakit dan mencari sumber informasi tentang patient safety dan menaikkan jenjang pendidikan yang lebih tinggi dan dapat dijadikan sebagai referensi bagi peneliti selanjutnya. Kepada peneliti selanjutnya supaya meneliti dengan memasukkan perawat yang ada di ruang IGD dan ICU.

\section{DAFTAR PUSTAKA}

Anriani, N. (2019). Pengetahuan perawat tentang keselamatan pasien dengan pelaksanaan prosedur Keselamatan Pasien Rumah Sakit (KPRS). doi: 10.31219/osf.io/bvgqn

Asfian, P., Mawansyah, L. T., \& Saptaputra, S. K. (2019). Hubungan pengetahuan sikap dan motivasi kerja perawat dengan pelaksanaan patient safety di Rumah Sakit Santa Anna Kendari 2017. Jurnal Ilmiah Mahasiswa Kesehatan Masyarakat, 2(6). doi: http://dx.doi.org/10.37887/ jimkesmas.v2i6.5444

Bantu, A., Mulyadi, N., \& Bidjuni, H. (2014). Hubungan pengetahuan perawat dengan penerapan identify patient correcly di RSUP Ratatotok Buyat Kabupaten Minahasa Tenggara. Jurnal Keperawatan, 2(2). https://ejournal.unsrat.ac.id/index.ph $\mathrm{p} / \mathrm{jkp} / \mathrm{article} / \mathrm{view} / 5647$

Bawelle, S. C., Sinolungan, J. S. V., \& Hamel, R. (2013). Hubungan pengetahuan dan sikap perawat dengan pelaksanaaan keselamatan pasien (patient safety) di ruang rawat inap RSUD Liun Kendage Tahuna. Jurnal Keperawatan, 1(1). https://ejournal.unsrat.ac.id/index.ph $\mathrm{p} / \mathrm{jkp} / \mathrm{article} / \mathrm{view} / 2237$

Cahyono, A. (2015). Hubungan karakteristik dan tingkat pengetahuan Perawat terhadap pengelolaan keselamatan pasien di rumah sakit. Jurnal Ilmiah WIDYA, l(1). http://ejournal.jurwidyakop3.com/index.php /jurnal-ilmiah/article/view/238

Darliana, D. (2016). Hubungan pengetahuan perawat dengan upaya penerapan patient safety di ruang rawat inap Rumah Sakit Umum Daerah DR. Zainoel Abidin Banda Aceh. Idea Nursing Journal, 7(1), 61-69.

http://www.jurnal.unsyiah.ac.id/INJ/a rticle/view/6469

Harus, B. D., \& Sutriningsih, A. (2015). pengetahuan perawat tentang keselamatan pasien dengan pelaksanaan prosedur Keselamatan 
Pasien Rumah Sakit (KPRS) di Rumah Sakit Panti Waluya Sawahan Malang. Care: Jurnal Ilmiah Ilmu Kesehatan, 3(1), 25-32. doi: http://dx.doi.org/10.33366/cr.v3i1.30 0

Listianawati, R. (2018). Hubungan pengetahuan perawat tentang keselamatan pasien (patient safety) dengan sikap perawat terhadap pemberian obat di ruang rawat inap kelas III RSUD Dr. Loekmono Hadi Kudus. Prosiding HEFA (Health Events for All). http://prosiding.stikescendekiautama kudus.ac.id/index.php/pros/article/vie w/303

Lombogia, A., Rottie, J., \& Karundeng, M. (2016). Hubungan perilaku dengan kemampuan perawat dalam melaksanakan keselamatan pasien (patient safety) di ruang akut instalasi gawat darurat RSUP Prof. Dr. RD Kandou Manado. Jurnal Keperawatan, 4(2). https://ejournal.unsrat.ac.id/index.ph $\mathrm{p} / \mathrm{jkp} /$ article/view/12916

Mannion, R., \& Braithwaite, J. (2017). False dawns and new horizons in patient safety research and practice. International Journal of Health Policy and Management, 6(12), 685. PMID: 29172374. doi: 10.15171/ijhpm.2017.115

Renoningsih, D. P., Kandou, G. D., \& Porotu'o, J. (2016). Faktor-faktor yang berhubungan dengan penerapan patient safety pada perawat di instalasi rawat inap Rumah Sakit Umum Pancaran Kasih GMIM Manado. Community Health, 1(3).

Setiyajati, A. (2014). Pengaruh pengetahuan dan sikap perawat terhadap penerapan standar keselamatan pasien di instalasi perawatan intensif RSUD Dr. Moewardi (Doctoral dissertation, UNS (Sebelas Maret University). https://digilib.uns.ac.id/dokumen/det ail/41806/
Sultana, M., Hossain, M. S., Ara, I., \& Sultana, J. (2018). Medical errors and patient safety education: views of intern doctors. Bangladesh Medical Research Council Bulletin, 44(2), 8288. doi: https://doi.org/10.3329/bmrcb.v44i2. 38701

Tutiany, L., \& Krisanti, P. (2017). Bahan ajar keperawatan: manajemen keselamatan pasien. PPSDM KEMENKES RI.

WHO. (2017). Patient safety: making health care safer (No. WHO/HIS/SDS/2017.11). World Health Organization. https://apps. who.int/iris/handle/10665/255507 